No 4078

Studia nad Autorytaryzmem i Totalitaryzmem 43, nr 4 Wrocław 2021

https://doi.org/10.19195/2300-7249.43.4.13

KATARZYNA TOMASZEWSKA

ORCID: 0000-0003-4024-0036

Uniwersytet Wrocławski

katarzyna.tomaszewska@uwr.edu.pl

\title{
Obowiązek posiadania dowodu osobistego i funkcje dowodów pod rządami dekretu z dnia 22 października 1951 roku o dowodach osobistych oraz w czasach współczesnych
}

Slowa kluczowe: dowody osobiste, obowiązek obywatelski, PRL, elektroniczny dowód osobisty, dekret o dowodach osobistych.

\section{OBLIGATION TO HAVE AN IDENTITY CARD AND THE FUNCTIONS OF IDENTITY \\ CARDS UNDER THE DECREE OF 22 OCTOBER 1951 ON IDENTITY CARDS \\ AND IN MODERN TIMES}

\begin{abstract}
The fulfilment of basic civic duties has always entailed the need for individuals to bear certain responsibilities. Their weight varies depending on the content of the obligation itself and the political system of the state in which the obligation is fulfilled. Such a claim is fully justified if we consider the obligation to have an identity card, defined by the content of the Decree of 22 October 1951 and the Act of 6 August 2010 on Identity Cards. The analysis of the above-mentioned regulations allows for: emphasizing the obligation's character as a basic civic duty, recalling the differences in the actual occurrence and social perception of ailments related to the implementation of the obligation to have an identity card in the times of the Polish People's Republic and in the 21st century, while referring to the similarities and differences resulting from the visual aspects and functionality of contemporary and historical ID cards.
\end{abstract}

Keywords: identity cards, civic duty, Polish People's Republic, electronic identity card, Decree on Identity Cards, Act on Identity Cards. 


\section{Wprowadzenie}

Dowód osobisty stanowi dokument potwierdzający tożsamość jednostki, do posiadania którego i do posługiwania się którym zobligowany jest każdy wypełniający odpowiednie warunki obywatel polski. Nie jest decyzją administracyjną ${ }^{1}$, ani też jego otrzymanie nie następuje wskutek wydania władczego rozstrzygnięcia, ale będąc dokumentem urzędowym, posiada szczególną wartość (chodzi o moc dowodową co do podmiotu wydającego oraz wewnętrznej zawartości) ${ }^{2}$. Posiada szczególne znaczenie dla każdej przeciętnej jednostki, mimo iż nie reprezentuje sobą żadnej wartości materialnej. Jak podkreślił w jednym z wyroków Sąd Apelacyjny w Lublinie: „Nie może być uznany za mienie, gdyż nie jest rzeczą mogącą w związku $\mathrm{z}$ tym być przedmiotem obrotu, ani też nie daje prawa do uzyskania mienia" 3 . $Z$ tego też tytułu ,jego zabór w celu przywłaszczenia nie stanowi przedmiotu przestępstwa określonego w art. $210 \S 1$ k.k."4. Niezależnie jednak od tego wiedza czy też świadomość ważności (doniosłości) dowodu osobistego po stronie obywateli uwidacznia się, z jednej strony, w dążeniu do zapewnienia mu odpowiedniej ochrony, $\mathrm{z}$ drugiej zaś - w chęci jego posiadania przez te jednostki, które powoli zbliżają się do pełnoletniości. Nie trudno się temu dziwić, albowiem posiadanie tego dokumentu od wieków w świadomości społecznej przesądzało (przesądza) o dorosłości, dojrzałości, prawie do bycia samodzielnym i niezależnym. Tego rodzaju podejście determinuje szczególną, niezależną od czasów i ustroju politycznego w państwie funkcję dowodu osobistego jako instrumentu, który otwiera nowy etap w życiu każdego człowieka. Nie posiada ona jednak żadnego prawnego znaczenia, choć nawiązuje do funkcjonalności wynikającej z przepisów o dowodach osobistych. Chodzi w tym wypadku o uregulowania dekretu z dnia 22 października 1951 roku o dowodach osobistych (dalej: dekret) ${ }^{5}$ oraz ustawy z dnia 6 sierpnia 2010 roku o tym samym tytule (dalej: u.d.o.) ${ }^{6}$. Stanowią one przedmiot analizy prowadzonej na gruncie niniejszego opracowania. Ma ona na celu ukazanie charakteru obowiązku posiadania dowodu osobistego i funkcji, którą pełnił w czasach PRL oraz uwidocznienie znaczenia dokumentów tożsamości, którymi posługuje się współczesna jednostka - człowiek XXI wieku. Dla potrzeb przybliżenia funkcjonalności dowodów osobistych nie bez znaczenia pozostaje ogólna ich charakterystyka od strony wizualnej, merytorycznej (treściowej) oraz formalnej związanej z wydawaniem przez

1 Por. Wyrok NSA z dnia 28 czerwca 2018 roku, II OSK 301/17, https://orzeczenia.nsa.gov. pl/doc/FED5D3ED0A (dostęp: 24.08.2021).

2 Z. Leoński, Materialne prawo administracyjne, Warszawa 2009, s. 72.

3 Wyrok SA w Lublinie z dnia 14 maja 1992 roku, II AKr 99/92, https://sip.lex.pl/\#/jurisprudence/520114861/1?directHit=true\&directHitQuery=II\%20AKr\%2099 2F92 (dostęp: 10.08.2021).

${ }^{4}$ Wyrok SN z dnia 5 grudnia 1985 roku, Rw 1090/85, https://sip.lex.pl/\#/jurisprudence /520113828/1?directHit=true\&directHitQuery=Rw\%201090 2F85 (dostęp: 10.08.2021).

5 Dz.U. z 1962 r. Nr 2, poz. 5.

6 Dz.U. z 2021 r. poz. 816 ze zm. 
odpowiednie podmioty publiczne, jak również nawiązującej do obligatoryjności posiadania i okazywania na wezwanie właściwych funkcjonariuszy publicznych.

\section{Posiadanie dowodu osobistego jako obowiązek obywatelski}

Każda jednostka żyjąca w danym państwie niezależnie od epoki, będąca częścią określonego społeczeństwa jest adresatem ogółu powinności, które wynikają z norm moralnych, obyczajowych, w szczególności zaś prawnych ${ }^{7}$. Te same przepisy, które determinują przysługujące jednostkom prawa i wolności, wytyczają obowiązki będące mniejszym lub też większym ciężarem dla obywateli. Uchwalona w 1952 roku Konstytucja Rzeczpospolitej Ludowej ${ }^{8}$ wyraźnie podkreśliła fakt umocnienia i rozszerzenia praw oraz wolności obywatelskich, wyznaczyła jednak ich katalog (podobnie jak katalog obowiązków) w oddzielnym, umiejscowionym pod koniec aktu rozdziale, to jest - w rozdziale 8 . Mimo iż katalog ten został określony jako podstawowy, to tego rodzaju prawa i obowiązki sformułowane zostały także $w$ innych częściach ustawy zasadniczej. Fakt ulokowania w ustawie zasadniczej nadał im szczególną rangę i wyniósł ponad wszystkie pozostałe powinności nawiązujące lub też odnoszące się do konstytucyjnych uzupełnianych lub rozwijanych w drodze ustawy 9 . Wbrew temu, czego można by się spodziewać przy uwzględnieniu daty uchwalenia konstytucji, jak również ze względu na potocznie odczytywane znaczenie dowodu osobistego, obligatoryjność jego posiadania nie została wyraźnie zdeterminowana w regulacjach konstytucyjnych z czasów PRL. Obowiązek jego posiadania nie został zakwalifikowany jako podstawowy, czyli taki, który dotyka najważniejszych interesów państwa oraz obywateli, który uwidacznia się w stopniu największym, biorąc pod uwagę istniejące $\mathrm{w}$ danym kraju stosunki polityczne, kontakty społeczne oraz etap jego rozwoju ${ }^{10}$. Niemniej jednak, jak wynikało $\mathrm{z}$ art. 8 ust. 2 Konstytucji PRL, ścisłe przestrzeganie praw stanowiło podstawowy obowiązek każdego organu i obywatela. Obywatel PRL miał przestrzegać przepisów konstytucji i ustaw oraz socjalistycznej dyscypliny pracy, szanować zasady współżycia społecznego, wypełniać sumiennie inne obowiązki wobec państwa (art. 90 Konstytucji RP). Jak zauważył Bogdan Dobkowski, w tej jednej regulacji fragmentarycznie zostały zarysowane aż cztery rozmaite zobowiązania zakwalifikowane do rangi najważniejszych grupy obowiązków podstawowych, które obejmują swoimi ramami również inne

${ }^{7}$ R. Wieruszewski, Podstawowe obowiazki obywateli PRL, Warszawa 1984, s. 65.

8 Konstytucja Polskiej Rzeczypospolitej Ludowej uchwalona przez Sejm Ustawodawczy w dniu 22 lipca 1952 roku (Dz.U. z 1952 r. Nr 33, poz. 232).

9 A. Łopatka, Pojęcie podstawowych praw i obowiazków obywateli PRL, [w:] Podstawowe prawa i obowiazki obywateli PRL, red. A. Łopatka, Warszawa 1968, s. 33.

10 Ibidem, s. 32. 
powinności obywatelskie ${ }^{11}$. Ogólny charakter przywołanego przepisu, to jest nieograniczanie się do jednego tylko zobowiązania, przede wszystkim zaś szeroko zakreślona powinność postępowania bez ścisłej konkretyzacji, utworzył podstawy do doszukiwania się $\mathrm{w}$ prawnie uregulowanym obowiązku posiadania dowodu osobistego zasadniczego znaczenia i pośrednio również konstytucyjnego charakteru. Jako uregulowany treścią dekretu, z jednej strony, wypływał z ogólnego i podstawowego zobowiązania obywateli do przestrzegania prawa, ale z drugiej sam z siebie nim nie był i w świetle literalnego brzmienia uregulowań konstytucji nie sposób mu było nadać przymiotu podstawowego obowiązku obywatelskiego. Wprawdzie ustawy i akty niższego rzędu wyznaczają nowe obowiązki po stronie obywateli, ale nie posiadają one tego podstawowego charakteru, który wynika $\mathrm{z}$ racji umiejscowienia określonej powinności jednostki w akcie najwyższej rangi $^{12}$. Dzieje się tak, mimo iż ich zasadnicze znaczenie potwierdziła jednoznacznie praktyka, a obowiązek respektowania podlegał stosunkowo częstej i niezorganizowanej weryfikacji. Tego rodzaju twierdzenie jest w pełni uzasadnione, jeśli weźmiemy pod uwagę występującą w czasach PRL częstotliwość legitymowania obywateli znajdujących się w danym momencie w prozaicznych sytuacjach. Każdy obywatel PRL miał obowiązek noszenia dowodu przy sobie i prezentowania go na dosyć powszechnie znane z tamtych czasów wezwanie: „dowód - a nierzadko nawet zdrobniale - dowodzik proszę"13. W myśl art. 17 dekretu dla potrzeb kontroli ruchu ludności organy Milicji Obywatelskiej mogły żądać okazania dowodu osobistego. Słusznie zauważył Zbigniew Nęcki, że dowody osobiste stanowiły narzędzie walki ówczesnej władzy, na którym praktyka PRL-owska opierała weryfikowanie swoich obywateli ${ }^{14}$.

Jak wynikało z zawartości art. 1 dekretu, każdy obywatel polski zamieszkały w kraju miał obowiązek posiadania dowodu osobistego od ukończenia 18 roku życia. Nie dotyczyło to osób umysłowo chorych podlegających wpisowi do dowodów osobistych swoich opiekunów. Podobnie sytuacja wyglądała w odniesieniu do osób niepełnoletnich i nieposiadających tymczasowego zaświadczenia tożsamości (art. 2 ust. 1 dekretu). Warto podkreślić, że mimo prawnie nałożonego zobowiązania dowody osobiste były wydawane jedynie tym osobom, których tożsamość oraz obywatelstwo zostało stwierdzone w sposób niebudzący żadnych wątpliwości. Jakakolwiek niepewność w tym zakresie skutkowała otrzymaniem przez jednostkę jedynie dokumentu zastępczego — zaświadczenia (art. 4 dekretu). Pod rządami ówcześnie obowiązujących przepisów posiadanie dowodu

11 B. Dobkowski, Konstytucyjne prawa i obowiazki obywateli PRL, Warszawa 1979, s. 269; oraz R. Wieruszewski, op. cit., s. 135.

12 A. Łopatka, op. cit., s. 183.

13 Zob. J. Kochanowski, Dowód (proszę), https://www.polska1918-89.pl/pdf/dowod-prosze, 1673.pdf (dostęp: 11.08.2021).

14 Z. Nęcki, Ludzie sa przyzwyczajeni do dowodów osobistych, https://www.radiokrakow.pl/ audycje/z-necki-ludzie-sa-przyzwyczajeni-do-dowodow-osobistych (dostęp: 11.08.2021). 
osobistego było jednym z ważniejszych, prawnych, niekonstytucyjnych obowiązków spoczywających na obywatelach PRL. Tak jak lekceważenie czy też naruszanie innych powinności było karalne, tak uchylanie się od czynienia zadość obowiązkowi posiadania dowodu osobistego było zagrożone sankcją — podlegało karze aresztu do lat dwóch lub też mogło doprowadzić do nałożenia grzywny w wysokości do 10 tysięcy złotych. Prawodawca dopuszczał również możliwość wymierzenia kary łącznej. Ważność posiadania i władania dowodem osobistym wynikała również z zawartości art. 16 ust. 1 dekretu, albowiem jego utrata wymagała niemalże natychmiastowego (bo w ciągu 24 godzin) przekazania informacji do najbliższego komisariatu lub też posterunku Milicji Obywatelskiej. To samo stanowisko, o większym ciężarze gatunkowym obowiązku posiadania dowodów osobistych w porównaniu do współczesnych czasów, można zająć przy uwzględnieniu treści Rozporządzenia Ministrów Bezpieczeństwa Publicznego i Finansów z dnia 22 grudnia 1952 roku o opłatach w sprawach dowodów osobistych i tymczasowych zaświadczeń tożsamości (dalej: rozporządzenie o opłatach) ${ }^{15}$. Kwoty pobierane tytułem wydania nowej dokumentacji w związku z uszkodzeniem lub utratą uprzedniej $\mathrm{w}$ istotny sposób przewyższały standardowe opłaty związane z pozyskiwaniem dowodów osobistych. Regulacje dokonywały stopniowania czynności (zdarzeń), jakie mogły mieć miejsce w odniesieniu do posiadania dowodu osobistego. Kwalifikowały jego zaginięcie jako zdarzenie szczególnie niepożądane i rodzące tym samym najcięższe konsekwencje natury finansowej po stronie posiadacza. Nierzadko zwyczajne zgubienie dowodu osobistego traktowane było jako dążenie do uchylenia się od innych obowiązków na rzecz państwa, a nawet mogło stanowić asumpt do oskarżenia jednostki za prowadzenie działalności wrogiej dla państwa i jego władzy ${ }^{16}$. Podwyższone opłaty, z jednej strony, miały działać odstraszająco, z drugiej zaś - mogły stanowić rzeczywistą karę za nieuwagę jednostki, jej lekkomyślność, niedbalstwo, zaniechanie odpowiednich działań zabezpieczających. Wynosiły odpowiednio $25 \mathrm{zł} \mathrm{w}$ przypadku uszkodzenia dowodu osobistego i $50 \mathrm{zł} \mathrm{w}$ przypadku jego zaginięcia (niezależnie od konkretnych przyczyn i okoliczności zagubienia dowodu osobistego). Dla porównania warto w tym miejscu nadmienić, że normalny (standardowy) koszt wydania dowodu osobistego wynosił 8 zł. Ponadto należy zauważyć, że ocena przydatności danego dokumentu, który uległ uszkodzeniu, i podjęcie decyzji o konieczności jego wymiany nie pozostawało w gestii jego posiadacza. Ogół przedstawionych rozważań prowadzi do konstatacji, że obowiązkowi posiadania dowodu osobistego towarzyszyły szczególne, choć nieopisane i nieuregulowane prawnie, ciężary związane z podejmowaniem działań na rzecz zapobieżenia uszkodzeniu lub zgubieniu dowodu osobistego. Wprawdzie nie zostało to usankcjonowanie treścią dekretu, ale pociągało za sobą szczególne reperkusje o charakterze

15 Dz.U. z 1952 r. Nr 51, poz. 338.

16 A. Dryszel, Plastikowa karta zastępuje papierowa książeczkę. Jest nowocześniej, ale czy na pewno lepiej?, https://www.tygodnikprzeglad.pl/historia-dowodow-osobistych/ (dostęp: 13.08.2021). 
finansowym związane z koniecznością pozyskania nowej dokumentacji. Sam zaś dowód osobisty (pomimo swojego namacalnego charakteru) nie stanowił dobyt$\mathrm{ku}$ - własności - obywatela, którą mógł on swobodnie władać. Owszem, to na posiadaczu spoczywał obowiązek dbałości i ochrony, ale o samej konieczności wymiany nie przesądzały tylko zdarzenia określone treścią obowiązujących przepisów (utrata ważności, brak miejsca na dokonywanie wpisów, zmiana nazwiska lub imienia), ale decydowanie w tym przedmiocie pozostawiono organom Milicji Obywatelskiej. Ponadto nie należy zapominać, że zgodnie z treścią art. 14 dekretu dowody osobiste na czas wyjazdu za granicę podlegały przedłożeniu właściwym organom ${ }^{17}$. Realizacja przedstawionego obowiązku została szczegółowo określona treścią Rozporządzenia Prezesa Rady Ministrów i Ministra Bezpieczeństwa Publicznego z dnia 15 grudnia 1952 roku w sprawie wykonania niektórych przepisów dekretu o dowodach osobistych ${ }^{18}$.

Pomimo wprowadzenia ustroju demokratycznego obligatoryjność posiadania dowodu została zachowana, z tym jednak, że złagodzono dolegliwości związane z lekceważeniem tego obowiązku, z niesumiennym jego wypełnianiem. Sam zaś charakter omawianego obowiązku przy uwzględnieniu sposobu i miejsca uregulowania nie wykazuje większych odmienności. Wynika to z zawartości obowiązujących regulacji, nadających mu znaczenie niekonstytucyjnej, choć istotnej powinności prawnej, ściśle powiązanej z obowiązkiem przestrzegania prawa RP (art. 83 Konstytucji RP) ${ }^{19}$. Wedle art. 5 ust. 2 u.d.o. pełnoletni obywatel Rzeczypospolitej Polskiej zamieszkujący na jej terytorium jest zobowiązany posiadać dowód osobisty. Jednocześnie jednak nie należy zapominać, że ten sam ustawodawca w ust. 1 art. $5 \mathrm{w}$ pierwszej kolejności odwołuje się do posiadania dowodu osobistego, kreując $\mathrm{z}$ tego faktu uprawnienie zagwarantowane określonym jednostkom, to jest — każdemu obywatelowi Rzeczypospolitej Polskiej, niezależnie od wieku czy zdolności do czynności prawnych ${ }^{20}$. Z jednej zatem strony, posiadanie dowodu osobistego jest administracyjnoprawnym obowiązkiem wynikającym wprost $\mathrm{z}$ regulacji ustawowych, ale $\mathrm{z}$ drugiej — każda osoba będąca obywatelem Rzeczypospolitej Polskiej, która jeszcze nie ukończyła 18 roku życia, ma prawo uzyskania dowodu osobistego po spełnieniu warunków określonych w ustawie. Dowód osobisty wydaje się niezależnie od faktu zameldowania i miejsca zamieszkania, co implikuje fakt, że obywatel na stałe zamieszkujący poza terytorium RP również dysponuje uprawnieniem do posiadania jednego ważnego dowodu osobistego (art. 6 u.d.o.).

17 Zob. też § 16 Rozporządzenia Ministra Spraw Wewnętrznych z dnia 19 lutego 1962 roku o właściwości organów i trybie postępowania w sprawach dowodów osobistych i tymczasowych zaświadczeń tożsamości oraz o wzorach tych dokumentów (Dz.U. z 1962 r. Nr 16, poz. 70).

18 Dz.U. z 1952 r. Nr 49, poz. 329.

19 Konstytucja Rzeczpospolitej Polskiej z dnia 2 kwietnia 1997 roku (Dz.U. z 1997 r. Nr 78 , poz. 483 ze zm.).

20 W. Maciejko, Ustawa o dowodach osobistych. Komentarz, LEX 2013. 
Od strony praktycznej należy zwrócić uwagę, że współcześnie inaczej wygląda świadomość jednostek w zakresie konieczności respektowania owej powinności i posiadania dowodu osobistego. Tego rodzaju świadomość opiera się głównie na dążeniu do sprawnego załatwienia określonych spraw urzędowych czy prywatnych, których nie tylko powodzenie, ale wręcz rozpoczęcie (możliwość procedowania) uzależnione jest od wylegitymowania się przez zainteresowanego dowodem osobistym. Nie chodzi zatem o posiadanie dowodu tylko dla potrzeb okazania na żądanie funkcjonariusza, ale i dokonania określonych czynności w przychodni, banku, u notariusza, w bibliotece, hotelu, na poczcie, u operatora telefonii komórkowej. Wykorzystanie dowodu osobistego jest na tyle pospolite, że współczesny człowiek rzadko skupia na tym swoją uwagę. Pozostaje to w ścisłym związku z rozszerzeniem jego funkcjonalności jako narzędzia identyfikacji (nośnika identyfikacji elektronicznej) ${ }^{21}$. I choć aktualnie można odnaleźć uregulowania z zakresu materialnego prawa administracyjnego, przewidujące obowiązek posiadania dowodu osobistego ,przy sobie" 22 , to jednak realna - faktyczna - obawa przed jego pozostawieniem $\mathrm{w}$ domu, chwilowym nieposiadaniem jest mniejsza w porównaniu do czasów PRL. Sam termin, w ciągu którego obywatel ma zgłosić fakt utraty dowodu osobistego, nie został precyzyjnie uregulowany. Ustawodawca posługuje się bliżej niedookreślonym pojęciem niezwłoczności, czyli wskazuje, że zawiadomienie powinno mieć miejsce tak szybko, jak tylko jest to możliwe (niekoniecznie w ciągu 24 godzin). Warto w tym miejscu zwrócić uwagę na stanowisko Wojciecha Maciejki, przy pomocy którego autor podkreśla, że skoro przepisy prawa w sposób wyjątkowy (bo w ściśle określonych sytuacjach) regulują przypadki obligatoryjnego posiadania przy sobie dowodu osobistego i powinność ta nie została wprost $\mathrm{i}$ wyraźne zaakcentowana ani w uprzednio obowiązującej Ustawie z dnia 10 kwietnia 1974 roku o ewidencji ludności i dowodach osobistych $^{23}$, ani w aktualnie obowiązującej u.d.o., należy uznać, że w rzeczywistości taki obowiązek - nieodłącznego i każdorazowego posiadania dowodu osobistego przez obywatela - nie występuje ${ }^{24}$. Niezależnie od niniejszego ustawodawca przewiduje (mimo iż łagodniejsze) sankcje za fakt nieposiadania dowodu osobistego (uchylania się od obowiązku jego wyrobienia lub wymiany). Chodzi w tym przypadku o karalność przewidzianą w sytuacji niezawnioskowania o wydanie dowodu osobistego, wówczas gdy powstał już obowiązek jego posiadania lub wymiany. Co więcej, w obliczu tak zwięzłego sformułowania (art. 79 pkt 1 u.d.o.)

21 K. Czaplicki, Biometryczny dowód tożsamości, „Monitor Prawniczy” 2020, nr 24, https:// sip.legalis.pl/document-full.seam?documentId=mjxw62zogi3damrygaztomi (dostęp: 24.08.2021).

22 Chodzi w tym wypadku między innymi o art. 18 ust. 1 Ustawy z dnia 21 czerwca 2002 roku o stanie wyjątkowym (Dz.U. z 2017 r. poz. 1928), art. 23 ust. 1 Ustawy z dnia 29 sierpnia 2002 roku o stanie wojennym oraz kompetencjach Naczelnego Dowódcy Sił Zbrojnych i zasadach jego podległości konstytucyjnym organom Rzeczypospolitej Polskiej (Dz.U. z 2017 r. poz. 1932), cyt. za: W. Maciejko, Osobowe prawo administracyjne, Warszawa 2008, s. 12.

23 Dz.U. z 2006 r. Nr 139, poz. 93 ze zm.

24 W. Maciejko, Osobowe..., s. 12-13. 
można uznać, że nic nie stoi na przeszkodzie, aby penalizacja obejmowała również sytuację długotrwałego nieodbierania przygotowanego dla wnioskodawcy dowodu osobistego. Przedstawiona powyżej karalność została zrównana z dolegliwościami, jakie mogą być odczuwalne po stronie osób dopuszczających się niezgodnych $\mathrm{z}$ prawem czynów polegających na zatrzymaniu bez podstawy prawnej cudzego dowodu osobistego lub też niezwracających dowodu osobistego w razie utraty obywatelstwa polskiego. W tych wszystkich przypadkach ustawodawca przewiduje odpowiedzialność za wykroczenie ${ }^{25}$. Na sprawcę czynu może być nałożona kara ograniczenia wolności lub grzywny.

\section{Wizualizacja i wydawanie dowodu osobistego z czasów PRL i XXI wieku}

Po zakończeniu wojny realizacja obowiązku posiadania dowodu osobistego została ugruntowana dekretem, ,pierwsze” jednak dowody pojawiły się dopiero w 1953 roku. Pod rządami dekretu kompetencje do wydawania dowodów posiadały komendy Milicji Obywatelskiej, których właściwość miejscowa była wyznaczana według miejsca zamieszkania zainteresowanego (art. 8 ust. 1 dekretu). Realizacja obowiązku posiadania dowodu osobistego wymagała zawnioskowania przez zainteresowanego, co pociągało za sobą konieczność przedłożenia organom wydającym stosownej dokumentacji. Obok bowiem formularza wniosku, który musiał zawierać poświadczenie miejsca pobytu (zamieszkania) przyszłego posiadacza dowodu, występowała również obligatoryjność przedłożenia odpisu skróconego aktu urodzenia lub aktu małżeństwa oraz trzech fotografii. Prawodawca oprócz wyznaczenia zakresu załączników do wniosku o wydanie dowodu osobistego uregulował również obowiązek przedłożenia do wglądu zaświadczenia z miejsca pracy lub nauki. Okazaniu podlegała także dokumentacja, która zawierała w swej treści informacje o tym, czym zajmuje się wnioskodawca lub też skąd czerpie środki finansowe na swoje utrzymanie. Tego rodzaju obligatoryjność obejmowała w odniesieniu do wybranych jednostek także wojskowy dokument osobisty lub zaświadczenie o zgłoszeniu się do rejestracji stwierdzające stosunek do powszechnego obowiązku wojskowego. Mimo iż nie wynikało to wprost z art. 9 dekretu, pozyskanie dowodu osobistego nie było bezpłatne. Wprawdzie, jak wynikało z treści rozporządzenia o opłatach, wszelkiego rodzaju podania, pisma i załączniki, świadectwa związane z uzyskaniem przez zainteresowanego dowodu osobistego nie wymagały uprzedniego uiszczenia opłaty, to samo odebranie dowodu osobistego pociągało za sobą należność w wysokości 8 zł. Kwalifikowane (bo jednak wyższe) kwoty przewidziane były w sytuacji dokumentacji wydawanej na skutek wymiany „starego” dowodu osobistego. Uregulowania aktu

25 Prawo administracyjne, red. J. Boć, Wrocław 2010, s. 445. 
wykonawczego utworzyły katalog przesłanek, których wypełnienie prowadziło do zwolnienia z opłaty. Od jej ponoszenia mogły być zwolnione osoby, których źródłem utrzymania było zaopatrzenie emerytalne, lub inwalidzi wojskowi, jak również osoby pobierające stosowne zasiłki oraz znajdujące się $\mathrm{w}$ trudnej sytuacji finansowej (ze względu na ich warunki materialno-bytowe). O zwolnieniu decydowała właściwa komenda Milicji Obywatelskiej. Weryfikacja przesłanek do zwolnienia przeprowadzana była $\mathrm{w}$ oparciu o zaświadczenie prezydium właściwej rady narodowej bądź na podstawie dokumentu, który potwierdzał fakt pobierania zasiłku.

Uwzględniając zawartość art. 10 i 11 dekretu, można nadmienić, że dowody z czasów PRL stanowiły zespół danych (były swoistą, opieczętowaną, indywidualną, papierową bazą danych) o obywatelach. Katalog informacji podlegających umieszczeniu w tak zwanej zielonej książeczce o miękkiej płóciennej okładce, ciemnozielonego koloru ( $\S 5$ ust. 1 rozporządzenia o właściwości) posiadał enumeratywny charakter. Niedopuszczalne bowiem było zamieszczenie w jego treści jakichkolwiek innych informacji czy wpisów poza tymi, które wynikały z treści obowiązującego prawa. Obok standardowych danych podlegających wpisowi w zawartości umieszczane były również informacje o stanie cywilnym, zawodzie, widniał rysopis posiadacza dowodu, określenie organu wydającego, wskazanie na osoby pozostające pod władzą rodzicielską lub opieką posiadacza dowodu, informacje o przyjęciu i zwolnieniu z pracy. Jedną z ważniejszych informacji widniejących $w$ dowodzie był adres zameldowania $\mathrm{i}$ informacje na temat wymeldowania. Na to przeznaczone było najwięcej stron dokumentu, albowiem zakładano, że obywatel między innymi w celu poszukiwania pracy będzie się przemieszczał, co każdorazowo wymagało nowego zameldowania i obligatoryjnego odnotowania tego faktu w dowodzie osobistym. Podobną wagę przypisywano informacjom o miejscu zatrudnienia.

Wygląd i zawartość dokumentów osobistych ulegał zmianie na przestrzeni lat, przede wszystkim zaś format książeczki z rubrykami, w których zamieszczane były stosowne wpisy, oraz z widniejącym na ostatniej stronie pouczeniem o odpowiedzialności karnej za naruszanie obowiązku przekształcił się w plastikową kartę, w której dokonywanie jakikolwiek adnotacji z racji samego materiału wykonania zostało wykluczone ${ }^{26}$. Choć pierwsze „plastikowe” dowody tożsamości pojawiły się w 2001 roku $^{27}$ i określone zostały mianem rewolucji XX wieku, to

26 Zob. też. T. Quintel, The Commission Proposal and EDPS Opinion 7/2018 on the Proposed Regulation Concerning Identity Cards of Union Citizens and Other Documents, „European Data Protection Law Review (EDPL)" 4, 2018, nr 4, s. 505-514.

27 Do 2 sierpnia 2021 roku obowiązywało Rozporządzenie Ministra Spraw Wewnętrznych i Administracji z dnia 7 stycznia 2020 roku w sprawie wzoru dowodu osobistego, jego wydawania i odbioru oraz utraty, uszkodzenia, unieważnienia i zwrotu (Dz.U. z 2020 r. poz. 31). Zostało ono uchylone na mocy Ustawy z dnia 14 kwietnia 2021 roku o zmianie ustawy o dowodach osobistych oraz niektórych innych ustaw (Dz.U. z 2021 r. poz. 1000). 
ich pierwotna postać oraz zawartość nie pozostały niezmienne. Dostrzeżone bra$\mathrm{ki}$, niedociągnięcia, błędy wynikające $\mathrm{z}$ wprowadzania do „obrotu” tego szczególnego novum pociągnęły za sobą konieczność wdrażania zmian i udoskonaleń zarówno co do wyglądu, jak i funkcjonalności dowodu osobistego. Na szczególną uwagę zasługuje fakt ograniczenia informacji, które przez wiele lat widniały w treści papierowego dokumentu. Nie bez znaczenia pozostaje również wykluczenie $\mathrm{z}$ treści dowodów danych dotyczących osób trzecich (art. 6 ust. 3 u.d.o.). Nie należy jednak zapominać, że zbiór danych o osobie umiejscowionych w aktualnym dowodzie osobistym to nie tylko to, co jest jawne i widoczne dla ludzkiego oka. Obok bowiem warstwy graficznej występuje również warstwa elektroniczna, czyli informacje zakodowane. Ta pierwsza obejmuje podstawowe dane dotyczące posiadacza dowodu oraz informacje o samym dokumencie. $\mathrm{Z}$ kolei w warstwie elektronicznej umieszczono dane dotyczące osoby, dowodu, informacje uwierzytelniające, jak również stosowne certyfikaty (art. 12 i 12a u.d.o.).

Jak zostało już wskazane, współczesny obowiązek posiadania dowodu osobistego w porównaniu do czasów PRL został złagodzony, a ciężar jego realizacji nie jest tak dotkliwy, jak to miało miejsce historycznie. Co istotne, nie chodzi w tym wypadku jedynie o miarkowanie ciężaru, które odwołuje się do obniżenia karalności przewidzianej na wypadek jego lekceważenia, ale też o zmniejszenie wagi zobowiązania wynikającego między innymi z przydzielenia kompetencji do wydawania przedmiotowej dokumentacji organom samorządowym (wójtowi, burmistrzowi, prezydentowi miasta). Podmiotami wydającymi dowody osobiste nie są już budzące negatywne odczucia i skojarzenia organy Milicji Obywatelskiej. Ponadto nie należy zapominać, że współczesne dowody osobiste są wydawane bez konieczności uiszczenia opłaty ${ }^{28}$. W tym właśnie można doszukiwać się również potwierdzenia dla określonego $\mathrm{w}$ art. 5 u.d.o. uprawnienia do posiadania dowodu osobistego. Skoro fakt ten $\mathrm{w}$ świetle obowiązujących uregulowań ma być pewnego rodzaju przywilejem, z którego mogą skorzystać obywatele RP, niezasadne byłoby żądanie uiszczenia należności jako zapłaty za jego przygotowanie i wydanie uprawnionemu. Przedłożenie wniosku o dowód osobisty nie wymaga stawienia się $w$ urzędzie właściwym ze względu na miejsce zameldowania danego obywatela. Co więcej, w ogóle nie wymaga się osobistego stawiennictwa przed organem, albowiem ustawodawca dopuszcza postać elektroniczną wniosku opatrzoną podpisem elektronicznym i przekazaną organowi przy pomocy środków komunikacji elektronicznej (art. 24 ust. 3 u.d.o.) ${ }^{29}$. Mniejszego ciężaru zobowiązania można również doszukiwać się w braku konieczności przedkładania rozbudowanego zestawu załączników na etapie wnioskowania o wydanie dowodu osobistego. To samo dotyczy samego odbioru przygotowanej przez

28 Por. Wyrok WSA w Rzeszowie z dnia 29 marca 2017 roku, II SA/RZ 1363/16, https:// orzeczenia.nsa.gov.pl/doc/42AD291C79 (dostęp: 24.08.2021).

${ }^{29}$ Zob. Wyrok WSA w Gdańsku z dnia 13 listopada 2015 roku, III SAB/Gd 28/15, https:// orzeczenia.nsa.gov.pl/doc/D9DB281868 (dostęp: 23.08.2021). 
organ dokumentacji - potwierdzenie tożsamości i obywatelstwa wnioskodawcy następuje w oparciu o ważny, choć „stary”, dowód osobisty lub dokument paszportowy, jak również poprzez porównanie danych widniejących w dokumentach z tymi umiejscowionymi w centralnych zbiorach danych, takich jak RDO oraz rejestr PESEL. Można również dokonać niniejszego przy użyciu innego dokumentu zawierającego fotografię wnioskodawcy. Dopuszczalne jest także dla potrzeb weryfikacji kierowanie pytań o nazwisko rodowe wnioskodawcy lub nazwiska rodowe rodziców, daty i miejsca ich urodzenia. Zwiększony zakres wymagań (choć wbrew pozorom niestanowiący większego obciążenia po stronie osoby ubiegającej się o wydanie dowodu osobistego) uwidacznia się w zakresie fotografii, która ma określać wizerunek przyszłego posiadacza dowodu osobistego. Ustawodawca w sposób szczegółowy determinuje jej warunki techniczne i wizualne, albowiem dowody nie są sporządzane w urzędzie gminy, ale przesyłane za pomocą systemu teleinformatycznego do RDO. Możliwość wprowadzenia obrazu do systemu jest uzależniona od spełnienia odpowiednich wymagań technicznych ${ }^{30}$ po to, aby w dalszej kolejności wizerunek obywatela został cyfrowo przeniesiony na wielowarstwową płytkę stanowiącą dowód osobisty. I choć mogą one stanowić pewnego rodzaju utrudnienie dla człowieka współczesnych czasów (który przyzwyczajony do wykonywania fotografii za pomocą telefonu może uznawać tego rodzaju wymogi za przesadne), to jednak nie należy zapominać o statusie i charakterze dowodu jako urzędowej dokumentacji. Wymaga ona bowiem zapewnienia jej jednolitości oraz zagwarantowania odpowiedniej powagi w prezentowanym wizerunku posiadacza.

\section{Identyfikacja, sygnowanie dokumentacji, przekraczanie granic - czyli zespół czynności, którym służył (służy) dowód osobisty}

Odnosząc się do funkcjonalności omawianej dokumentacji, można pokusić się o stwierdzenie, że dowód kojarzy się z udogodnieniami. Rodzi przekonanie, że fakt jego posiadania powinien jednostce coś dawać (jakieś przywileje). Słusznie zauważa Abdur Rahman Khan, że bez możliwości identyfikacji, którą daje dowód osobisty, nie można wykonywać obowiązków obywatelskich (na przykład w zakresie głosowania), ani też czerpać z korzyści, jakie daje obywatelom państwo ${ }^{31}$. Wiąże się to z szeregiem funkcji, którym dowód służył historycznie i współcześnie. Posłużenie się jednak tego rodzaju twierdzeniem w odniesieniu do czasów

30 Zob. Wyrok WSA w Gliwicach z dnia 3 marca 2017 roku, II SA/G1 728/16, https://orzeczenia.nsa.gov.pl/doc/CBC27696CF (dostęp: 23.08.2021).

31 A. Rahman Khan, National Identity Card: Opportunities and Threats, „Journal of Asian Research" 2, 2018, nr 2, s. 79. 
PRL może rodzić uzasadnione wątpliwości, w szczególności jeśli weźmiemy pod uwagę charakterystykę ówczesnych czasów. Nie wynikało to wprawdzie z zawartości art. 5 dekretu, niemniej jednak akty wykonawcze wydane na jego podstawie wyraźnie potwierdziły, że fakt posiadania dowodu pociągał za sobą dodatkowe obowiązki po stronie obywatela. W świetle art. 5 dowody osobiste i tymczasowe zaświadczenia tożsamości były jedynymi dokumentami przeznaczonymi do potwierdzenia tożsamości danego obywatela. Jednocześnie stanowiły wyłączną dokumentację, na podstawie której można było dokonać zameldowania i wymeldowania danej osoby. Warto w tym miejscu podkreślić, że (wbrew temu, co wynika z przywołanej regulacji) korzyści po stronie obywatela wynikające z możliwości potwierdzenia swojej tożsamości czy też posiadanego meldunku miały jedynie pozorny charakter. $\mathrm{W}$ rzeczywistości bowiem działania polegające na potwierdzaniu tożsamości czy miejsca zameldowania danej osoby bardziej służyły władzy i kontroli przez nią wykonywanej niż samemu obywatelowi. Ponadto samo otrzymanie dowodu osobistego rodziło nowe powinności po stronie obywatela. Ich treścią było uzyskanie stosownych wpisów (nie w dowolnym, ale w ściśle wyznaczonym terminie), począwszy od faktu samego zameldowania, poprzez posiadany lub zmieniony stan cywilny, aż po informacje o dacie przyjęcia do pracy i zwolnieniu z pracy. Stosowne wpisy umieszczały organy ewidencji i kontroli ruchu ludności, urzędy stanu cywilnego oraz państwowe i spółdzielcze zakłady pracy, bądź też organizacje o znaczeniu ogólnopaństwowym (§ 7-10 rozporządzenia o właściwości). Mogły one wzywać posiadaczy do przedłożenia dowodów osobistych i tymczasowych zaświadczeń celem umiejscowienia w ich treści prawem wymaganych adnotacji ( $\$ 11$ rozporządzenia o właściwości). Ich istotność potwierdzała konieczność wymiany dowodu osobistego wówczas, gdy zabrakło już miejsca na dokonywanie nowych wpisów (art. 13 ust. 1 pkt 3 dekretu). Uwidaczniająca się na gruncie uregulowań dekretu i aktów wykonawczych funkcjonalność omawianej dokumentacji potwierdziła, że prawidłowa realizacja obowiązku posiadania dowodu osobistego, podobnie jak meldunkowego, uzyskania paszportu czy też pozwolenia na broń miała służyć i służyła ochronie takich wartości, jak bezpieczeństwo i porządek publiczny ${ }^{32}$. A zatem służba na rzecz jednostki miała jedynie pośrednie znaczenie i odbywała się nierzadko kosztem obywatela między innymi na skutek stosowanego przymusu, inwigilacji i represji. Nie jest bowiem tajemnicą, że w okresie PRL owe wartości (bezpieczeństwo i porządek publiczny) zajmowały szczególnie wysoką pozycję, jeśli chodzi o hierarchię wszystkich wartości społecznych ${ }^{33}$. To ich utrzymaniu miały służyć nie tylko działania kontrolne (następcze), ale również prewencyjne związane z uchwalaniem i wdrażaniem restrykcyjnych uregulowań prawnych.

32 E. Smoktunowicz, Encyklopedia obywatela PRL, Warszawa 1987, s. 171.

33 Ibidem. 
Głębsza analiza użyteczności dowodów osobistych uwidacznia pewnego rodzaju zależność: im mniejsza zawartość treściowa dowodu osobistego, tym szerszy zakres funkcji, którym służy. Pozostaje to w ścisłym związku z postępującym procesem informatyzacji w administracji publicznej, a ściślej mówiąc - z występowaniem elektronicznych zbiorów danych o obywatelach (PESEL, RSC, RDO), jak również z wdrażaniem nowych rozwiązań prawno-informatycznych, na przykład podpisu elektronicznego (osobistego), które poszerzają jego współczesne zastosowanie. Współczesny dowód osobisty, mimo że podstawowy, nie jest jedynym (albowiem nie wskazuje na to jednoznacznie sam ustawodawca) dokumentem, na podstawie którego dokonuje się potwierdzenia tożsamości i obywatelstwa polskiego $^{34}$. Ponadto, jak wynika z zawartości u.d.o., dowód osobisty przyznaje legitymację do przekraczania granic państw, o których mowa w art. 4 u.d.o., i mimo iż nie wynika to bezpośrednio z u.d.o., jego posiadanie daje możliwość legalnego zatrudnienia jednostki poza terytorium RP oraz korzystania z przysługującego obywatelom danego państwa wsparcia w ramach gwarantowanej obywatelom UE swobody przepływu osób ${ }^{35}$. Może być wykorzystywany: ufanego ${ }^{36}$;

— dla uwierzytelnienia posiadacza w usługach online za pomocą profilu za-

— dla złożenia podpisu osobistego;

— dla potwierdzenia obecności danej osoby w określonym miejscu i czasie;

- jako kwalifikowane urządzenie przeznaczone do składania podpisu elektronicznego ${ }^{37}$ (kwalifikowanego podpisu elektronicznego).

Dodatkowe funkcje współczesnego dowodu osobistego jako instrumentu potwierdzającego tożsamość jednostki można wyprowadzić z treści uregulowań Ustawy z dnia 5 stycznia 2011 roku o kierujących pojazdami ${ }^{38}$. W myśl bowiem art. 3 ust. 4 osoba, która ukończyła 18 rok życia, nie ma obowiązku posiadania dokumentu stwierdzającego posiadane uprawnienie do kierowania rowerem, wózkiem rowerowym lub pojazdem zaprzęgowym. W tym przypadku dokumentem podlegającym ewentualnej weryfikacji jest dowód osobisty jako potwierdzenie osiągnięcia prawem wymaganego wieku. Podobnie sytuacja wygląda w zakresie osoby kierującej motorowerem. Dotyczy to jednak tylko tych jednostek, które przed dniem wejścia w życie ustawy ukończyły 18 rok życia (art. 133 ust. 4). Na

34 Por. Wyrok SN z 4 stycznia 1977 roku, I KR 243/76, https://sip.lex.pl/\#/jurisprudence /520110668/1 directHit=true\&directHitQuery=I\%20KR\%20243 2F76 (dostęp: 24.08.2021).

35 Zob. art. 3 ust. 2 Traktatu o Unii Europejskiej (Dz.Urz. UE C 326 z 26.10.2012), s. 13; art. 21 Traktatu o funkcjonowaniu Unii Europejskiej (Dz.Urz. C 326 z 26.10.2012), s. 47.

${ }^{36}$ Zob. art. 3 pkt 14 Ustawy z dnia 17 lutego 2005 roku o informatyzacji działalności podmiotów realizujących zadania publiczne (Dz.U. z 2021 r. poz. 670 ze zm.).

37 Zob. Rozporządzanie Parlamentu Europejskiego i Rady UE nr 910/2014 z 23 lipca 2014 roku w sprawie identyfikacji elektronicznej i usług zaufania w odniesieniu do transakcji elektronicznych na rynku wewnętrznym oraz uchylającego dyrektywę 1999/93/WE (Dz.Urz. UE L 257 z 28.08.2014, s. 73).

38 Dz.U. z 2021 r. poz. 112. 
zakończenie warto podkreślić, że wielofunkcyjność współczesnego dowodu osobistego oraz obligatoryjność jego posiadania przesądzają o niedopuszczalności jego zatrzymania $\mathrm{w}$ związku $\mathrm{z}$ orzeczeniem wobec podejrzanego nieizolacyjnego środka zapobiegawczego w postaci zakazu opuszczania kraju (art. 277 § 1 Ustawy z dnia 6 czerwca 1997 roku — Kodeks postępowania karnego $\left.{ }^{39}\right)^{40}$.

\section{Zakończenie}

Posiadanie dowodu osobistego można zaliczyć do tak zwanych innych, bo niekonstytucyjnych, ale jednak prawnie uregulowanych obowiązków obywatelskich. Ogólna jego charakterystyka prowadzi do wniosków, że owe zobowiązanie jest (bez względu na „epokę”) wymagającym rzetelnego wypełnienia nakazem określonego postępowania, zgodnym z normami moralnymi żądaniem ze strony państwa, którego dobrowolna realizacja ma służyć ochronie zarówno interesu indywidualnego, jak i zbiorowego ${ }^{41}$. Co jednak ważne, ciężar realizacji tego zobowiązania pod rządami dekretu był bardziej odczuwany w porównaniu do współczesnych czasów. Zostało to podyktowane okolicznościami, które towarzyszyły samemu procesowi wydawania dokumentacji, jak i wynikało z funkcji, którym miał służyć pozostający we władaniu danej jednostki dowód osobisty. Przedstawiona w opracowaniu funkcjonalność dowodu osobistego z czasów PRL potwierdziła, że podstawowe znaczenie odgrywała funkcja identyfikacyjna związana z możliwością stwierdzania tożsamości jednostki i w jej następstwie kontrolowania. Miała ona służyć celom związanym z utrzymaniem porządku wewnętrznego w państwie. Ponadto nie należy zapominać, że obowiązek tak zwanego wyrobienia i posiadania dowodu osobistego miał działać stymulująco i wychowawczo na obywatela po to, aby wzbudzać jego społeczną aktywność, wzmacniać poczucie patriotyzmu i odpowiedzialności za dalsze losy całego kraju ${ }^{42}$. Współczesny dowód osobisty pomimo istotnych zmian, w materiale, przy użyciu którego został stworzony, wyglądzie i ograniczonej zawartości treściowej, nie utracił swojego znaczenia jako dokumentacja urzędowa, a ciężar samego zobowiązania związanego z posiadaniem dowodu i posługiwania się nim nie jest tak dotkliwy, jak miało to miejsce dawniej. Od strony funkcjonalnej trzeba podkreślić, że nieustannie służy tym samym celom - ma przede wszystkim potwierdzać tożsamość danej jednostki i jej obywatelstwo. Słusznie podkreślają Erich Schweighofer i Walter Hötzendorfer, że w tych wszystkich przypadkach, w których chodzi o większą dozę pewności

39 Dz.U. z 2021 r. poz. 534 ze zm.

40 K. Dudka, Praktyka stosowania nieizolacyjnych środków zapobiegawczych w polskim procesie karnym, LEX 2016.

41 R. Wieruszewski, op. cit., s. 233; F. Siemieniewski, Podstawowe wolności, prawa i obowiązi obywateli PRL, Warszawa 1979, s. 284.

42 Ibidem, s. 234 
co do identyfikacji danej jednostki, warto posłużyć się jej dowodem osobistym ${ }^{43}$. W związku ze zmianą ustroju politycznego utraciło swoje znaczenie traktowanie go jako instrumentu wnikliwego kontrolowania obywatela przez władzę - tego, gdzie pracuje, czy i ile ma dzieci, z czego się utrzymuje, gdzie stale zamieszkuje. W istotny zaś sposób rozwinęła się funkcja związana $\mathrm{z}$ przyznawaniem obywatelom szczególnych uprawnień, gwarantowaniem im określonych przywilejów i kreowaniem szczególnych udogodnień w zakresie przemieszczania się oraz sygnowania dokumentacji przybierającej postać elektroniczną.

\section{Bibliografia}

Banasik K., Dokumenty stwierdzające tożsamość, „Prokuratura i Prawo” 2018, nr 6.

Berutowicz W., Mokry J., Organizacja ochrony prawnej w PRL, Warszawa 1987.

Czaplicki K., Biometryczny dowód tożsamości, „Monitor Prawniczy” 2020, nr 24, https://sip.legalis. $\mathrm{pl} /$ document-full.seam?documentId=mjxw62zogi3damrygaztomi.

Dobkowski B., Konstytucyjne prawa i obowiazki obywateli PRL, Warszawa 1979.

Dryszel A., Plastikowa karta zastęuje papierowa ksiażeczkę. Jest nowocześniej, ale czy na pewno lepiej?, https://www.tygodnikprzeglad.pl/historia-dowodow-osobistych/.

Dudka K., Praktyka stosowania nieizolacyjnych środków zapobiegawczych w polskim procesie karnym, LEX 2016.

Leoński Z., Materialne prawo administracyjne, Warszawa 2009.

Lopatka A., Pojęcie podstawowych praw i obowiazków obywateli PRL, [w:] Podstawowe prawa i obowiazki obywateli PRL, red. A. Łopatka, Warszawa 1968.

Łopatka A., Wieruszewski R., Podstawowe prawa i obowiazki obywateli PRL w okresie budowy rozwiniętego społeczeństwa socjalistycznego, Warszawa 1976.

Kluska B., PESEL w PRL, Łódź 2019.

Kochanowski J., Dowód (prosze), https://www.polska1918-89.pl/pdf/dowod-prosze,1673.pdf.

Maciejko W., Osobowe prawo administracyjne, Warszawa 2008.

Maciejko W., Ustawa o dowodach osobistych. Komentarz, LEX 2013.

Nęcki Z., Ludzie sa przyzwyczajeni do dowodów osobistych, https://www.radiokrakow.pl/audycje/znecki-ludzie-sa-przyzwyczajeni-do-dowodow-osobistych.

Quintel T., The Commission Proposal and EDPS Opinion 7/2018 on the Proposed Regulation Concerning Identity Cards of Union Citizens and Other Documents, „European Data Protection Law Review (EDPL)" 4, 2018, nr 4.

Prawo administracyjne, red. J. Boć, Wrocław 2010.

Rahman Khan A., National Identity Card: Opportunities and Threats, „Journal of Asian Research” 2, 2018, $\mathrm{nr} 2$.

Schweighofer E., Hötzendorfer W., Electronic identities - public or private, „International Review of Law, Computers \& Technology" 27, 2013.

Siemieniewski F., Podstawowe wolności, prawa i obowiazki obywateli PRL, Warszawa 1979.

Smoktunowicz E., Encyklopedia obywatela PRL, Warszawa 1987.

Sokolewicz W., O socjalistycznej koncepcji podstawowych praw i obowiazków obywateli, „Studia Prawnicze" 1978, nr 2.

Torański B., Knebel. Cenzura w PRL-u, Warszawa 2016.

43 E. Schweighofer, W. Hötzendorfer, Electronic identities - public or private, „International

Review of Law, Computers \& Technology” 27, 2013, s. 230. 
Wawrzyniak J., Równość obywateli w PRL, Warszawa 1977.

Wieruszewski R., Podstawowe obowiązi obywateli PRL, Warszawa 1984.

\section{Wykaz aktów prawnych}

Dekret z dnia 22 października 1951 roku o dowodach osobistych (Dz.U. z 1962 r. Nr 2, poz. 5).

Karta Praw Podstawowych Unii Europejskiej (Dz.Urz. UE C 326 z dnia 26.10.2012).

Konstytucja Polskiej Rzeczypospolitej Ludowej uchwalona przez Sejm Ustawodawczy w dniu 22 lipca 1952 roku (Dz.U. z 1952 r. Nr 33, poz. 232).

Konstytucja Rzeczpospolitej Polskiej z dnia 2 kwietnia 1997 roku (Dz.U. z 1997 r. Nr 78, poz. 483 ze zm.).

Rozporządzenie Ministrów Bezpieczeństwa Publicznego i Finansów z dnia 22 grudnia 1952 roku o opłatach w sprawach dowodów osobistych i tymczasowych zaświadczeń tożsamości (Dz.U. z 1952 r. Nr 51, poz. 338).

Rozporządzenie Ministra Spraw Wewnętrznych z dnia 19 lutego 1962 roku o właściwości organów i trybie postępowania w sprawach dowodów osobistych i tymczasowych zaświadczeń tożsamości oraz o wzorach tych dokumentów (Dz.U. z 1962 r. Nr 16, poz. 70).

Rozporządzenie Ministra Spraw Wewnętrznych i Administracji z dnia 7 stycznia 2020 roku w sprawie wzoru dowodu osobistego, jego wydawania i odbioru oraz utraty, uszkodzenia, unieważnienia i zwrotu (Dz.U. z 2020 r. poz. 31).

Rozporządzanie Parlamentu Europejskiego i Rady UE nr 910/2014 z dnia 23 lipca 2014 roku w sprawie identyfikacji elektronicznej i usług zaufania w odniesieniu do transakcji elektronicznych na rynku wewnętrznym oraz uchylającego dyrektywę 19999/93/WE (Dz.Urz. UE L 257 z dnia 28.08.2014).

Rozporządzenie Prezesa Rady Ministrów i Ministra Bezpieczeństwa Publicznego z dnia 15 grudnia 1952 roku w sprawie wykonania niektórych przepisów dekretu o dowodach osobistych (Dz.U. z 1952 r. Nr 49, poz. 329).

Traktat o funkcjonowaniu Unii Europejskiej (Dz.Urz. C 326 z dnia 26.10.2012).

Traktat o Unii Europejskiej (Dz.Urz. UE C 326 z dnia 26.10.2012).

Ustawa z dnia 10 kwietnia 1974 roku o ewidencji ludności i dowodach osobistych (Dz.U. z 2006 r. $\mathrm{Nr} 139$, poz. 93 ze zm.).

Ustawa z dnia 6 czerwca 1997 roku — Kodeks postępowania karnego (Dz.U. z 2021 r. poz. 534 ze zm.).

Ustawa z dnia 21 czerwca 2002 roku o stanie wyjątkowym (Dz.U. z 2017 r. poz. 1928).

Ustawa z dnia 29 sierpnia 2002 roku o stanie wojennym oraz kompetencjach Naczelnego Dowódcy Sił Zbrojnych i zasadach jego podległości konstytucyjnych organom Rzeczypospolitej Polskiej (Dz.U. z 2017 r. poz. 1932).

Ustawa z dnia 17 lutego 2005 roku o informatyzacji działalności podmiotów realizujących zadania publiczne (Dz.U. z 2021 r. poz. 670 ze zm.).

Ustawa z dnia 6 sierpnia 2010 roku o dowodach osobistych (Dz.U. z 2021 r. poz. 816 ze zm.).

Ustawa z dnia 5 stycznia 2011 roku o kierujących pojazdami (Dz.U. z 2021 r. poz. 112).

Ustawa z dnia 14 kwietnia 2021 roku o zmianie ustawy o dowodach osobistych oraz niektórych innych ustaw (Dz.U. z 2021 r. poz. 1000).

Zarządzenie Ministra Spraw Wewnętrznych z dnia 14 czerwca 1956 roku w sprawie ustalenia przypadków, w których złożenie dowodu osobistego lub tymczasowego zaświadczenia tożsamości przy wyjazdach a grancie — na czas pobytu za granicą — nie jest wymagane (M.P. z 1956 r. Nr 56, poz. 611).

Zarządzenie Ministra Spraw Wewnętrznych z dnia 4 kwietnia 1962 roku w sprawie określenia organizacji społecznych obowiązanych do dokonywania wpisów w dowodach osobistych i tym- 
czasowych zaświadczeń tożsamości zatrudnionych u nich osób o dacie przyjęcia do pracy i zwolnienia (M.P. z 1962 r. Nr 32, poz. 149).

Zarządzenie Ministrów Obrony Narodowej i Bezpieczeństwa Publicznego z dnia 20 stycznia 1953 roku w sprawie dowodów osobistych żołnierzy (M.P. z 1953 r. Nr A-10, poz. 145).

\section{Wykaz orzecznictwa}

Wyrok NSA z dnia 28 czerwca 2018 roku, II OSK 301/17, https://orzeczenia.nsa.gov.pl/doc/FED5D3ED0A.

Wyrok SN z 4 stycznia 1977 roku, I KR 243/76, SIP LEX, https://sip.lex.pl/\#/jurisprudence /520110668/1 directHit=true\&directHitQuery=I\%20KR\%20243 2F76.

Wyrok SN z dnia 5 grudnia 1985 roku, Rw 1090/85, SIP Lex, https://sip.lex.pl/\#/jurisprudence /520113828/1?directHit=true\&directHitQuery=Rw\%201090 2F85.

Wyrok WSA w Gdańsku z dnia 13 listopada 2015 roku, III SAB/Gd 28/15, https://orzeczenia.nsa. gov.pl/doc/D9DB281868.

Wyrok WSA w Gliwicach z dnia 3 marca 2017 roku, II SA/G1 728/16, https://orzeczenia.nsa.gov. $\mathrm{pl} / \mathrm{doc} / \mathrm{CBC} 27696 \mathrm{CF}$.

Wyrok WSA w Rzeszowie z dnia 29 marca 2017 roku, II SA/RZ 1363/16, https://orzeczenia.nsa. gov.pl/doc/42AD291C79.

Wyrok SA w Lublinie z dnia 14 maja 1992 roku, II AKr 99/92, SIP Lex, https://sip.lex.pl/\#/jurisprudence/520114861/1?directHit=true\&directHitQuery=II\%20AKr\%2099 2F92. 